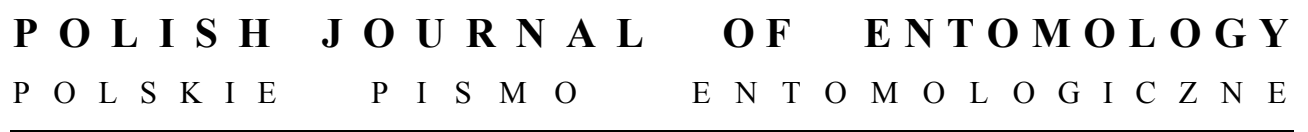

VOL. 80: $53-82$

Gdynia

31 March 2011

DOI: $10.2478 / \mathrm{v} 10200-011-0006-3$

\title{
New species of Hynhamia RAZOWSKI and other genera close to Toreulia RAZOWSKI \& BECKER (Lepidoptera: Tortricidae)
}

\author{
JÓZEF RAZOWSKI*, VITOR O. BECKER* \\ *Institute of Systematics and Evolution of Animals, Polish Academy of Sciences, \\ Sławkowska 17, 31-016 Kraków, Poland, \\ e-mail: Razowski@isez.pan.krakow.pl; \\ **Reserve Serra Bonita, PO Box 01, 45880-970 Camacan, BA, Brazil, \\ e-mail: Becker.vitor@gmail.com
}

\begin{abstract}
Seven genera and 24 species are treated; two genera (Ayazua gen. n., Ibateguara gen. n.) and 20 species (Hynhamia albicorpus sp. n., H. bahiana sp. n., H. diversa sp. n., H. patatea sp. n., Ayazua hyeroglyphica sp. n., Ramaperta telemaca sp. n., Brusqeulia guaramiranga sp. n., $B$. ceriphora sp. n., B. uncicera sp. n., B. costispina sp. n., $B$. bonita sp. n., B. tineimorpha sp. n., $B$. atrograpta sp. n., B. caracagena sp. n., B. baeza sp. n., B. monoloba sp. n., B. jacupiranga sp. n., B. atrocentra sp. n., Limeulia cimoliochroa sp. n., Ibateguara spinosissima $\mathrm{sp}$. n.). Paraneulia RAZOWSKI \& BECKER, 1999 is synonimized with Hynhamia RAZOWSKI, 1987.
\end{abstract}

KEY WORDS: Tortricidae, Hynhamia, genera allied with Toreulia, Euliini, new taxa, Neotropics.

\section{INTRODUCTION}

The genus Hynhamia RAzowsKi, 1987 was recently revised by RAzOwSKI \& PeLZ (2007). Originally, its putative autapomorphies were listed but no comparative diagnosis was provided. Hynhamia is certainly a euliine genus resembling Brusqeulia RAZOWSKI \& BECKER, 2000, especially in the shape of the uncus and valva. Its systematic position is still obscure chiefly because of the presence of the hami. We conjecture, however, that the hami could have appeared independently in the Euliini. Apart from this genus, hami have been 
found in Dimorphopalpa BROWN.

We include the following genera of Euliini in the Toreulia group: Toreulia RAzOWSKI \& BeCKer, 2000a: 111; Pinhaisania RAzowski \& BeCKer, 2000; Ayazua gen. n.; Ramaperta RAZOWSKI \& BECKER, 2000b: 385; Brusqeulia RAZOWSKI \& BECKER, 2000b: 386; Joaquima RAzowsKI \& BECKER, 1999: 410; Corneulia RAzOwSKI \& BECKER, 1999: 413; Marcelina RAzowsKi \& BeCKeR, 2000b: 388; Saopaulista RAzowsKi \& BeCKER, 2000b: 388; Limeulia RAzowsKI \& BeCKER, 2000b: 389; Pinhaisania RAzowsKI \& BECKER, 2000b: 387; Ibateguara gen. n.; Placabis RAzOWSKI \& BECKER, 2000a: 112.

Originally, each genus was described on the basis of the putative autapomorphies, and comparative diagnoses were provided for some others. For three genera, the diagnoses are updated in the systematic part of this paper. The remaining comparative diagnoses are as follows.

Marcelina is related to Brusqeulia, as shown by the shapes of the uncus, gnathos, transtilla and some other parts of the male genitalia. It differs from the latter genus and other closely related genera chiefly in the brachiola-like distal part of the valva and the setose posterior part of the costa.

Saopaulista was characterized by the configuration of the end of the gnathos and aedeagus; the transtilla resembles that in Marcelina and Brusqeulia and base of the uncus that of Limeulia.

Placabis has a separate position within the group as characterized by the presence of the strong scent organs bound to the pedunculi of the tegumen, the broad attachment of the sclerites of muscles M4, and the very distinct saccular part of the valva. The base of the uncus resembles that in Limeulia and Saopaulista, but the aedeagus is quite different: slender as in Ramaperta but opened dorsally and with a long coecum penis.

The material studied was collected by the junior author, chiefly in Brazil. The holotypes of the newly described species are preserved in the Becker Collection and will eventually be transferred to one of the museums in Brazil. The numbers cited on the labels are the entry numbers of the specimens in the register book of the above-mentioned collection.

\section{Acknowledgements}

We are grateful to Mr. Krzysztof Fiołek, Kraków, for the photographs of the moths and the arrangement of the plates. We also thank Mr. Witold Zajda, Kraków, who set up the specimens for photography, dissected the moths and arranged the genitalia plates.

\section{SYSTEMATICS}

Hynhamia RAZOWSKI, 1987

Hynhamia Razowski, 1987, Bulletin de l'Académie Polonaise des Sciences, Série des Sciences 
Biologiques 35: 69; type-species: Tortrix hemileuca MEYrick, 1932.

Paraneulia RAzowsKi \& BeCKer, 1999, Polskie Pismo Entomologiczne 68: 408; type-species:

Paraneulia perampla RAZOWSKI \& BECKER, 1999 - syn. n.

\section{Remarks}

Hynhamia was erected in the Chlidanotini as a monotypic genus (RAZOWSKI 1987). Then BROWN (1990) described two further species in this genus: he transferred H. cornutia to Netechma RAzOWSKI, 1992 but included Eulia sciodryas MEYRICK, 1926 in it. He also questioned the original position of Hynhamia and transferred it to the Euliini. Moreover, he suspected that the structures, interpreted by RAZOWSKI as hami, were in fact socii.

RAZOWSKI \& PELZ (2007) listed 11 species, describing six new ones from Ecuador. They rectified the interpretation of the hami, which certainly occur in this genus. Now, as many as 17 species are placed in this genus.

RAZOWSKI \& BECKER (1999) described Paraneulia and its two representatives (Hynhamia perampla RAZOWSKI \& BECKER, 1999 - comb. n., Hynhamia cerina RAZOWSKI \& BECKER, 1999 - comb. n.) from Brazil. The discovery of several species intermediate between Paraneulia and Hynhamia allows us to interpret them as synonymous.

\section{Hynhamia albicorpus sp. $\mathbf{n}$.}

(Figs 1, 2, 40)

\section{Diagnosis}

This species is externally very similar to $H$. decora RAZOWSKI \& PELZ, 2007 from Pichincha Province, Ecuador, but in albicorpus the forewing costa is white from base to apex, the gnathos tapering weakly terminad without an apical process, and the median part of transtilla is broad.

\section{Description}

Wingspan $15 \mathrm{~mm}$. Head and thorax white; labial palpus 2. Forewing as in decora. Ground colour cream; suffusions pale brownish cream. Markings pale brown consisting of costal halves of usual type; median fascia broadly diffuse in median area of wing. Cilia damaged. Hindwing cream with weak brownish spots in posterior area; cilia white.

Male genitalia (Figs 1, 2). Uncus long, broad in basal third, slender medially then gradually expanding terminad; socius long, hamus small; arm of gnathos large, broadest medially; valva slender with ill-defined neck; transtilla broad medially; aedeagus fairly long, slender.

Female not known.

\section{Material examined}

Holotype male: "Brasil: S[ăo]P[aulo], Jacupiranga 800 m, 8 II 1993, V.O. Becker Col; 
Coll. Becker 87546"; GS 260.

\section{Etymology}

The name refers to the colouration of the moth; Latin: corpus - a body, albus - white.

\section{Hynhamia bahiana sp. n.}

(Figs 3, 4, 41)

\section{Diagnosis}

H. bahiana is closely related to decora and albicorpus as the shapes of the uncus and gnathos show, but the transtilla of this species is similar to that in H. hemileuca (MEYRICK, 1932) from Colombia and the valva is very slender medially. It differs from cerina, bahiana in the larger lateral corners of the transtilla, the uniformly broad median part of the gnathos arm, the longer aedeagus and the coecum penis.

\section{Description}

Wingspan $16 \mathrm{~mm}$. Head and thorax white. Ground colour of forewing cream, suffusions brownish, well developed in costal half of wing. Markings brownish, atrophying in dorsal area, brown at costa. Cilia cream suffused brown. Hindwing cream, slightly mixed with yellowish brown at apex; cilia whitish.

Male genitalia (Figs 3, 4). Uncus large, broadening basally, expanding somewhat terminally; socius rather well sclerotized, naked, curved near base; hamus small; gnathos arm large, slender, rounded apically; valva slender, forming a slender cucullus; sacculus angulate; group of spines at ventral incision of valva; transtilla broad with lateral projections; aedeagus slender, long; coecum penis long.

Female not known.

\section{Material examined}

Holotype male: "Brasil: BA[hia], Camaca 400-700 m, 21-30 IX 1991, V.O. Becker Col; Col. Becker 84391"; GS 270.

\section{Etymology}

The name refers to Bahia, the state of origin of this species.

\section{Hynhamia diversa sp. $\mathrm{n}$.}

(Figs 5, 6, 42)

\section{Diagnosis}

This species is externally similar and closely related to decora but diversa has a subterminally broad gnathos arm. 

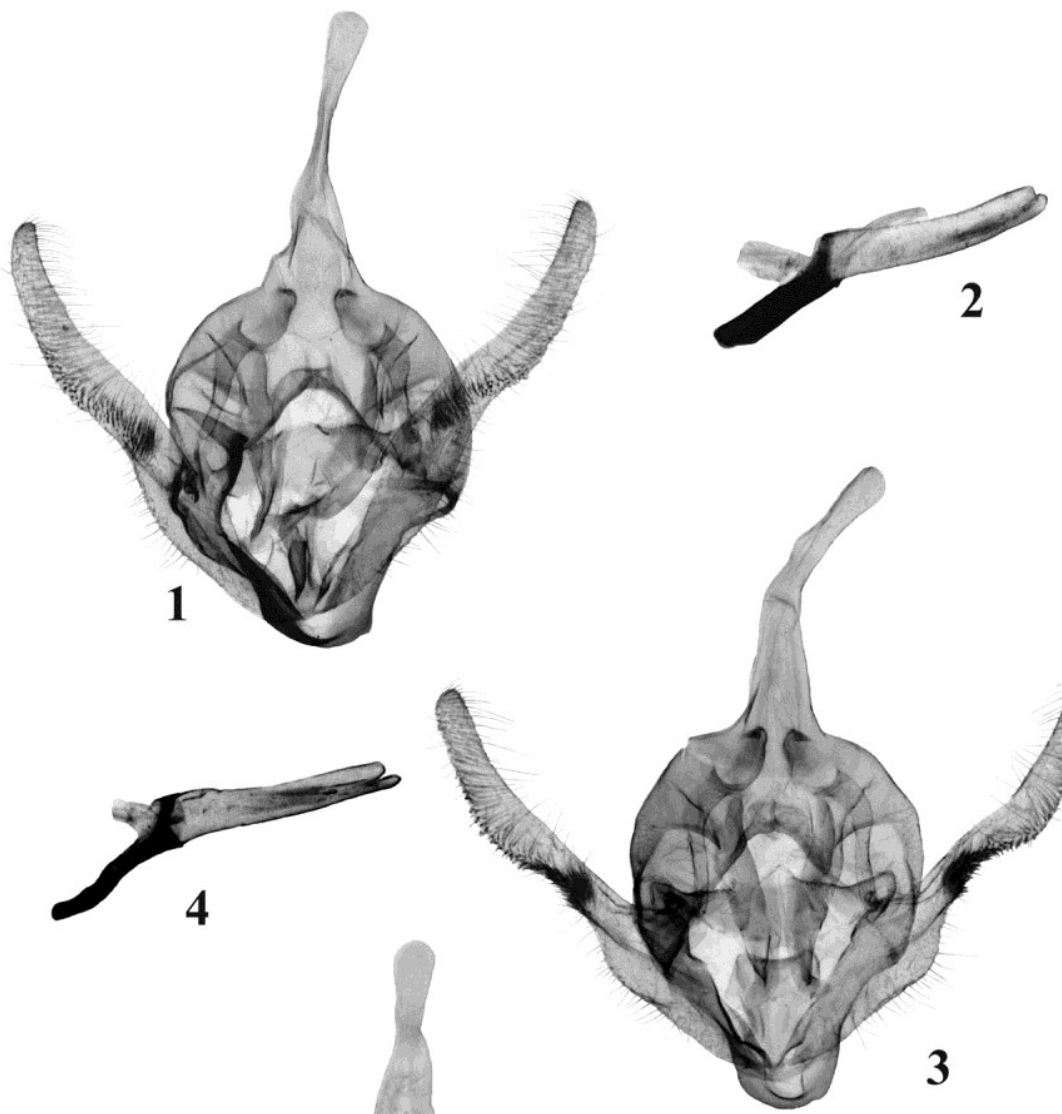

3

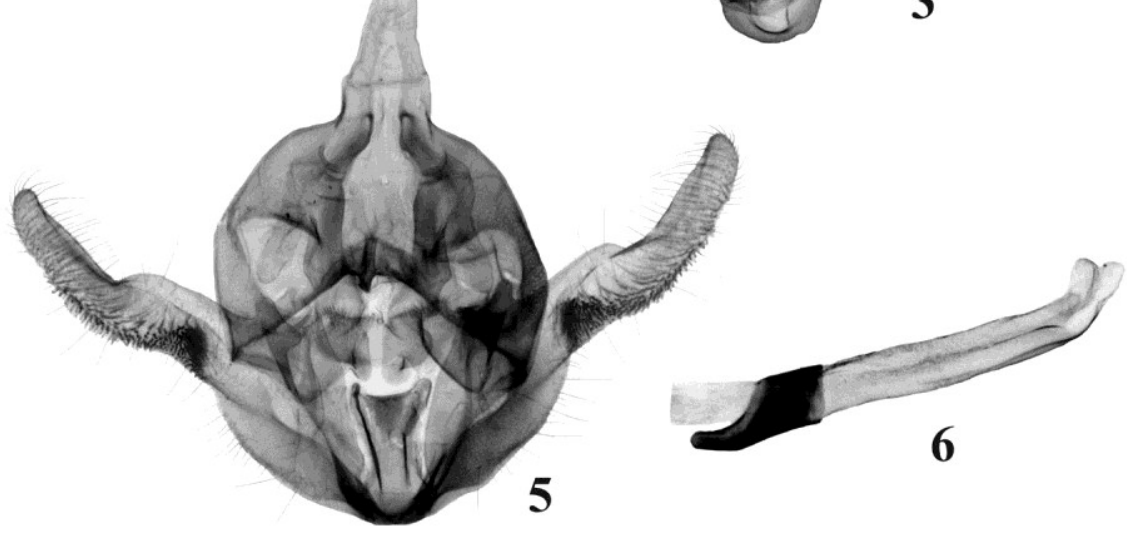

Figs 1-6. Male genitalia. 1, 2 - Hynhamia albicorpus sp. n., holotype; 3, 4-Hynhamia bahiana sp. n., holotype; 5, 6 - Hynhamia diversa sp. n., holotype. 


\section{Description}

Wingspan $19.5 \mathrm{~mm}$. Head, thorax and shape of forewing as in the two preceding species. Ground colour cream tinged and partly suffused yellowish brown. Markings yellowish brown, brown at costa, broader than in the preceding species, broad but diffuse in terminal area of wing. Cilia (worn) brownish. Hindwing cream tinged yellowish and spotted greyish costo-apically; cilia cream.

Male genitalia (Figs 5, 6). Uncus long, slender near middle, broad basally, gradually expanding terminad; socius long, slender, naked; hamus minute; arm of gnathos large, broad medially and subterminally, with small, rounded termination; basal half of costa of valva expanding dorsally, with a rather weak neck, spined submedially; transtilla spined dorsally, tapering medially; aedeagus simple, slender.

Female not known.

\section{Material examined}

Holotype male: Ecuador: Carchi, Maldonado 2200 m, 9-11 I 1993, V.O. Becker Col; Col. Becker 105217"; GS 284.

\section{Etymology}

The name refers to the difference from decora; Latin: diversa: different.

Hynhamia nigropunctana RAzowsKi \& Pelz, 2007

\section{Material examined}

One male from Ecuador, Prov. Azuay (Cajas 3150 m, 23 XII 1992).

\section{Remarks}

This species was described from the Province of Loja, Ecuador, where it was collected at an altitude of $2850 \mathrm{~m}$.

\section{Hynhamia patatea sp. $\mathrm{n}$.}

(Figs 7, 8)

\section{Diagnosis}

H. patatea differs from micruncus in having broad wings and very broad transtilla processes.

\section{Description}

Wingspan $26 \mathrm{~mm}$. Head and thorax brownish cream; labial palpus 3.5, slender, whiter 
terminally. Forewing broad with costa weakly curved outwards, apex rounded and termen straight, slightly oblique. Ground colour cream with slight brown admixture, pale ferruginous cream from base to end of median cell; suffusions and dots brownish. Cilia cream. Hindwing whitish cream, cilia similar.

Male genitalia (Figs 7, 8). Uncus slender; socii drooping, situated on broad posterior base; vinculum broad, strongly sclerotized; transtilla short with very large lateral processes and attachment processes for muscles 4; juxta elongate, concave dorsally; aedeagus long, slender; coecum penis slender; cornuti not found.

Female not known.

\section{Material examined}

Holotype male: "Ecuador: Tung.[urahua Province] Patate 3000 m, 7 XII 1992, V.O. Becker Col, Col. Becker 100119"; GS 86.

\section{Etymology}

The specific name is based on the name of the type locality.

\section{Toreulia RAZOWSKI \& BECKER, 2000}

\section{Remarks}

This genus was originally described as containing three Ecuadorian species and was compared with Ecuadorica RAZOWSKI \& BECKER, 2000 (= Anopinella POWELL, 1986). RAZOWSKI et al. (2007) redefined this genus and described seven species (four new ones).

\section{Toreulia basalis RAZOWSKI \& BECKER, 2000}

\section{Material examined}

One male from Ecuador (Maldonado, Carchi, 2200 m, 9-11 I 1993).

\section{Remarks}

This species was described from the same province, Carchi.

\section{Ayazua gen. n.}

Type-species: Ayazua hyeroglyphica sp. $\mathrm{n}$.

\section{Diagnosis}

Ayazua is close to Toreulia but differs from it in the presence of the posteriorly thorny arms of the gnathos, the reduction of the terminal plate of the gnathos, and the absence of the transtilla. 


\section{Description}

Forewing rather slender, markings limited to costal spots.

Male genitalia. Tegumen broad, short; uncus long, slender, tapering terminally; socius submembranous, drooping, hairy; gnathos arm rather long with terminal sharp process and three subterminal thorns; vinculum slender; valva slender, broad basally, with well developed costa; sacculus short, angulate, followed by well sclerotized ventral margin of valva; transtilla membranous; juxta moderate, with dorsal prominences; aedeagus short, rather slender; cornuti not realized.

Female not known.

\section{Distribution and biology}

A monotypic genus known from Ecuador, collected at $3150 \mathrm{~m}$.

\section{Etymology}

The generic name is an anagram of the name of the Province of Azuay.

\section{Ayazua hyeroglyphica sp. $\mathbf{n}$.}

(Figs 9, 10, 43)

\section{Diagnosis}

This species is the only representative of the genus; see its diagnosis.

\section{Description}

Wingspan $30 \mathrm{~mm}$. Head cream, browner laterally, with vertex brownish cream; labial palpus 4.5 brown laterally; thorax brownish cream with dark brown blotches and terminal third of tegula mixed whitish. Ground colour pale brownish cream, whiter along costa and dorsum, sprinkled cinnamon brown, whitish at tornus; venation cinnamon brown; dark brown intervenal lines in terminal and tornal area; slightly paler reticulation dorsally, dark brown transverse lines at tornus. Cilia cream with brownish divisions. Hindwing cream with pale greyish strigulation; cilia cream.

Male genitalia (Figs 9, 10) as described for the genus.

\section{Material examined}

Holotype male: "Ecuador: Azuay, Cajas, 3150 m, 23 XII 1992, V.O. Becker Col; Col. Becker 103277"; GS 150.

\section{Etymology}

The name refers to the colouration of the forewing: Greek/Latin: hieroglyphicus hieroglyphic. 

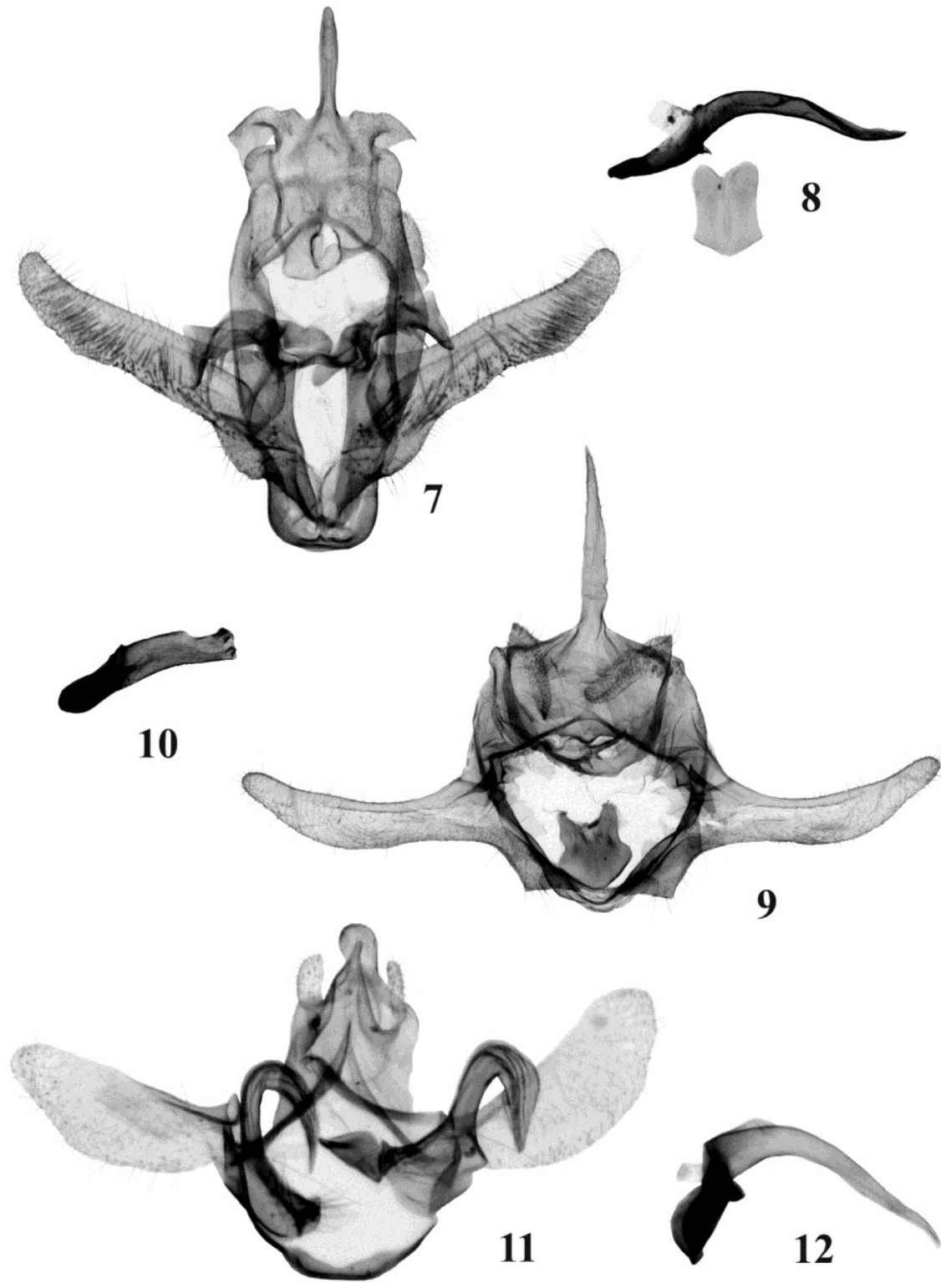

Figs 7-12. Male genitalia. 7, 8- Hynhamia patatea sp. n., holotype; 9, 10 - Ayazua hyeroglyphica sp. n., holotype; 11, 12 - Ramaperta telemaca sp. n., holotype. 


\section{Remarks}

Ramaperta RAZOWSKI \& BECKER, 2000

This monotypic genus was described on the basis of three putative autapomorphies (the ventral slit of the aedeagus, the extremely short zone of the aedeagus, and the hooked ventral termination of the sacculus) but was not compared with any other genus. It is closely related to Brusqeulia in that it has a similar uncus and transtilla but differing radically from the latter in the aedeagus.

\section{Ramaperta telemaca sp. n.}

(Figs 11, 12, 44)

\section{Diagnosis}

This, the second species of Ramaperta RAZOWSKI \& BECKER, 2000, differs from $R$. perarmata RAZOWSKI \& BECKER, 2000 from the State of Santa Catarina in the long basal part of the free termination of the sacculus and the long aedeagus.

\section{Description}

Wing span $10 \mathrm{~mm}$. Head whitish cream, labial palpus ca 1.5 ; thorax slightly browner than head. Forewing slender, rather uniformly broad throughout; termen moderately oblique. Ground colour cream. Markings pale brownish yellow; basal blotch to 1/3 of wing, with browner posterior edge; median fascia slender, connected with dorsal blotch; subapical blotch slender almost reaching median cell; terminal blotch long. Cilia whitish cream. Hindwing pale brownish grey, cilia whiter.

Male genitalia (Figs 11,12) as in perarmata but sacculus of telemaca long; transtilla a simple, slender band; aedeagus long, slender terminally.

Female not known.

\section{Material examined}

Holotype male: "Brasil: P[a]R[aná], 750 m, Telemaco Borba, 13-19 X 1995, V.O. Becker Col; Col. Becker 97785"; GS 335. Paratype from Săo Paulo 800 m, Caraguatuba, 1 V 1995, Col. Becker 96425 .

\section{Etymology}

The name refers to the type locality.

\section{Brusqeulia RAZOWSKI \& BECKER, 2000}

\section{Remarks}

This genus was erected to include three new Brazilian species. In this paper a further 12 species are described, only one of which is Ecuadorian. In Brazil, the range of this genus 
extends from Bahia south to Santa Catarina and Paraná, and only one species comes from the central part of the country (from the Federal District). In the male genitalia, the Ecuadorian species is close to several species from eastern Brazil (e.g. monoloba from Minas Gerais); hence, one may assume that further species will be found in the western part of the continent.

No pair of any species was discovered, and only one female (caracagena) is included in this genus on the basis of external similarity.

Brusqeulia is closely related to Toreulia, from which it differs in the size and pattern of the forewing; three representatives of this genus are small, narrow winged, with separate costal markings; the transtilla is usually slender (exception: monoloba), often with dorsolateral processes.

Brusqeulia sebastiani RAZOWSKI \& BECKER, 2000

\section{Material examined}

Two males from Paraná, Brazil (Quatro Barras, 900 m, 31 I 1993).

\section{Remarks}

This species was described from two males collected in Banhado, Quatro Barras, at the altitude of $800 \mathrm{~m}$.

\section{Brusqeulia guaramiranga sp. $\mathbf{n}$.}

\section{Diagnosis}

(Figs 13, 14, 45)

This species is externally similar and related to sebastiani but is easily distinguished by the presence of a row of blackish brown terminal spots, the broad termination of the sacculus, and the large sublateral lobes of the transtilla.

\section{Description}

Wing span $11.5 \mathrm{~mm}$. Head brownish cream, labial palpus 1.3, blackish, cream in distal third; thorax brownish cream, grey proximally. Forewing slender, hardly expanding terminally; costa convex at base, then straight; termen obliquely straight. Ground colour glossy whitish mixed with brownish cream chiefly in basal and terminal parts of wing, suffusions slightly darker; row of blackish brown spots along termen. Markings grey with distinct black spots consisting of incomplete postbasal fascia and costal triangle. Cilia concolorous with suffusions. Hindwing and cilia greyish, basal part of wing whiter.

Male genitalia (Figs 13, 14). Uncus moderate, rather slender, rounded apically; socius short; gnathos arms slender, terminal plate rounded apically; valva broad basally, with 
strong costa and rather short posterior part; sacculus broadly sinuate ventrally, with broad, rounded apically free termination; transtilla rather weakly sclerotized with median fold and large sublateral lobes; aedeagus broad except for terminal portion; cornuti a long row of small spines.

Female not known.

\section{Material examined}

Holotype male: "Brasil: CE[ara] 1000 m, Guaramiranga, 9 VI 1994, V. O. Becker Col; Col. Becker 92160"; GS 310. Paratype.

\section{Etymology}

The specific name refers to the type locality.

\section{Brusqeulia ceriphora sp. $\mathbf{n}$.}

(Figs 15, 16, 46)

\section{Diagnosis}

This species is related to guaramiranga but in ceriphora, the sacculus has a sharp free termination and small processes of the transtilla; externally ceriphora resembles Limeulia cimoliochroa chiefly in the uniform ground colour of the forewing.

\section{Description}

Wingspan $12 \mathrm{~mm}$. Head cream, frons and terminal third of labial palpus (1.5) brownish cream, remaining part of palpus brownish; thorax slightly tinged brownish. Forewing not expanding terminad with termen distinctly oblique. Ground colour cream in basal and terminal area mixed brownish pink; marginal dots blackish. Markings black consisting of postbasal fascia convex posteriorly and costal blotch consisting of two spots and subapical spot; the latter connected with tornal area by a black fascia. Cilia concolorous with posterior part of wing. Hindwing brownish cream, cilia paler.

Male genitalia (Figs 15, 16). Uncus rather strongly broadening basally; socius moderate; arm of gnathos slender, terminal plate oval, marked with transverse folds; valva broad in basal part, slender terminally; costa straight; sacculus deeply sinuate with strong, sharp free termination; transtilla with two well sclerotized dorsal thorn-like processes; aedeagus broad anteriorly, with slender terminal part; coecum penis broad; cornuti several slender, small spines.

Female not known.

\section{Material examined}

Holotype male: "Brasil: R[io de]J[aneiro], Nova Friburgo 800 m, 22 I 1993, V.O. 
Becker Col; Col. Becker 86016"; GS 435. Paratype an identically labelled male.

\section{Etymology}

The name refers to the processes of the transtilla; Greek: cera (from keras) - horn, phoreo - I carry.

\section{Brusqeulia uncicera sp. $\mathbf{n}$.}

(Figs 17, 18, 47)

\section{Diagnosis}

Though similar to guaramiranga, uncicera has a white forewing ground colour and a slender terminal process to the uncus.

\section{Description}

Wingspan ca $11 \mathrm{~mm}$. Head and thorax white, thorax slightly mixed with grey posteriorly. Forewing slender; costa somewhat curved at base; termen oblique, straight. Ground colour white with some refractive scales; dots black and grey. Markings black represented by dorso-basal spot, two larger spots at mid-costa and subapically and a streak parallel to them; cilia tinged pinkish. Hindwing whitish grey to middle, brownish grey on peripheries; cilia grey.

Male genitalia (Figs 17, 18). Uncus broad to middle, slightly narrowing near base, slender, long postmedially; socius small; arm of gnathos rather broad; valva slender; sacculus weakly concave before middle, with large free termination; transtilla a simple rod; aedeagus slender, bent, pointed ventro-terminally; coecum penis slender; cornuti small.

Female not known.

\section{Material examined}

Holotype male: "Brasil: M[inas] G[erais], Caraca 1300 m, 25 X 1994, V.O. Becker \& K. Sattler Col; Col. Becker 93549"; GS 346.

\section{Etymology}

The name refers to the shape of the uncus; Greek: keras - a horn.

\section{Brusqeulia costispina sp. $\mathbf{n}$.}

(Figs 19, 20, 48)

\section{Diagnosis}

The facies resemble that of uncicera, but costispina has grey maculation on the forewing and a sharp postmedian spine on the costa of the valva. 

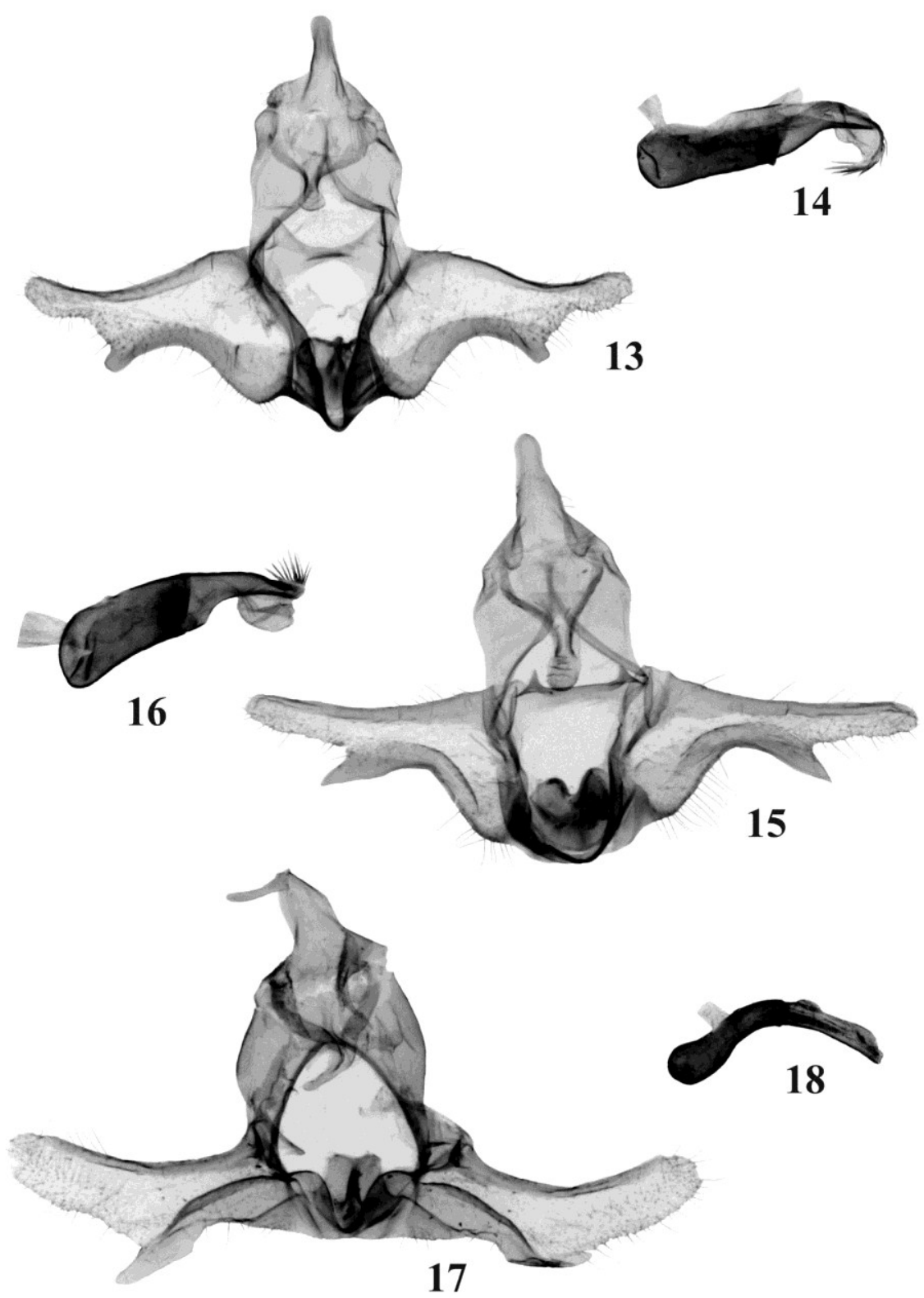

Figs 13-18. Male genitalia. 13, 14 - Brusqeulia guaramiranga sp. n., holotype; 15, 16 - Brusqeulia ceriphora sp. n., holotype; 17, 18 - Brusqeulia uncicera sp. n., holotype. 

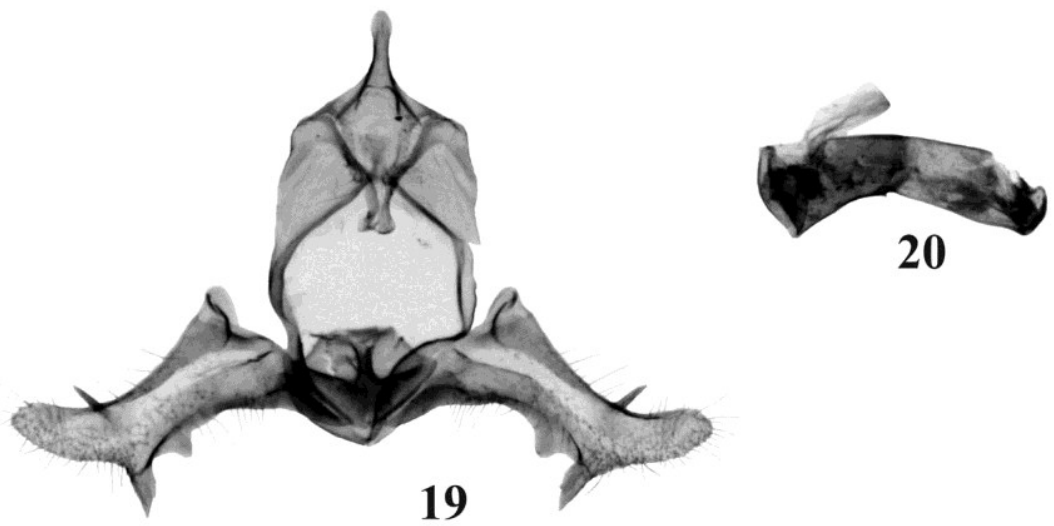

20

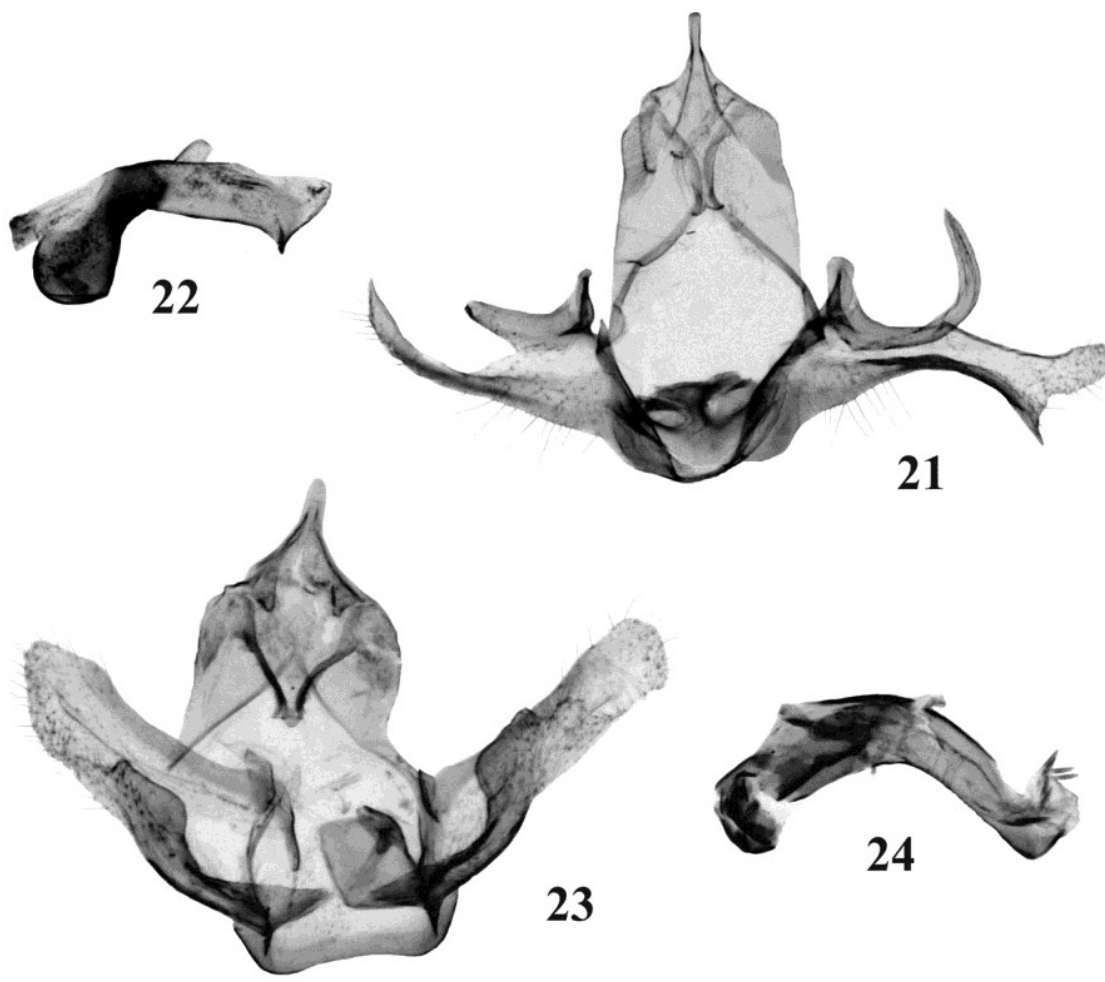

Figs 19-24. Male genitalia. 19, 20 - Brusqeulia costispina sp. n., holotype; 21, 22 - Brusqeulia bonita sp. n., holotype; 23, 24 - Brusqeulia tineimorpha sp. n., holotype. 


\section{Description}

Wingspan $10 \mathrm{~mm}$. Head and thorax white, collar grey. Forewing as in the two preceding species. Ground colour whitish sprinkled greyish; suffusions and strigulae grey; row of darker spots along termen. Markings grey consisting of costal part of postbasal fascia and spots in median and posterior part of costa. Cilia cream tinged ochreous. Hindwing brownish grey, transparent and pale in basal half; cilia similar.

Male genitalia (Figs 19, 20). Uncus moderate, slightly tapering in terminal part apically; socius small; arm of gnathos broadening terminally, terminal plate small; valva broad basally; strong spine beyond middle of costa; sacculus sinuate with postmedian lobe and strong, sharp terminal process; juxta large; aedeagus broad with ventro-terminal prominence.

\section{Material examined}

Holotype male: "Brasil: E[spitiro]S[anto], Linhares 40 m, 5-9 IV 1992, V.O. Becker Col.; Col. Becker 82928"; GS 375.

\section{Etymology}

The specific epithet refers to the presence of the costal spine of the valva; Latin: spina a spine.

\section{Brusqeulia bonita sp. $\mathrm{n}$.}

(Figs 21, 22, 49)

\section{Diagnosis}

Though externally very similar to costispina, bonita has a diffuse ferruginous dorsopostbasal blotch on the forewing; the male genitalia of the two differ distinctly, bonita having very strong basal processes of the transtilla and with no spine on the costa of the valva.

\section{Description}

Wing span $11 \mathrm{~mm}$. Head and thorax whitish grey; labial palpus 1.5 with median part of terminal joint blackish; proximal part of thorax blackish. Forewing not expanding terminally; costa almost straight; termen straight, moderately oblique. Ground colour whitish grey; suffusions greyish, some strigulae blackish grey; diffuse, pale ferruginous spots dorso-postbasally and subterminally. Cilia grey; median line dotted black. Hindwing greyish, paler basally, cilia similar.

Male genitalia (Figs 21, 22). Uncus slender; socius long, drooping; arm of gnathos slightly broadening terminally; valva broad at base, short beyond sacculus; sacculus slender medially, broadly sinuate, with sharp ventral termination; base of transtilla with very large, 
sclerotized hook; aedeagus broad with ventral termination.

Female not known.

\section{Etymology}

The name refers to the type locality: Bonito.

\section{Material examined}

Holotype male: "Brasil: BA[hia], Bonito 1000 m, 25 IV 1991, V.O. Becker Col; Col. Becker 78544"; GS 353.

\section{Brusqeulia tineimorpha sp. $\mathbf{n}$.}

(Figs 23, 24, 50)

\section{Diagnosis}

This species is related to Brusqeulia tripuncta RAZOWSKI \& BECKER, 2000 from Paraná, Brazil, and the three following species, but tineimorpha is distinguished by its very slender wings and their greyish colouration, and the large, broad aedeagus without a ventroterminal thorn.

\section{Description}

Wingspan $10 \mathrm{~mm}$. Head and thorax greyish white, collar darker, labial palpus 1.5. Forewing slender, costa rather uniformly convex, termen distinctly oblique. Ground colour whitish cream, reticulation and some larger strigulae brownish; remnants of markings in form of some brown costal spots. Cilia creamish grey with grey basal line. Hindwing grey, whiter basally; cilia greyish.

Male genitalia (Figs 23, 24). Uncus moderate, tapering terminally; socius small, rather well sclerotized; arms of gnathos slender; vinculum broad; valva rather slender; sacculus broadening basally and ventro-posteriorly; transtilla a simple band; aedeagus large, pointed ventro-terminally; cornuti six short spines.

Female not known.

\section{Material examined}

Holotype male: "Brasil: D[istrito]F[ederal], Planaltina 1000 m, 15.35'S 47.42'W, 15 IV 1985, V.O. Becker Col; Col. Becker 57417"; GS 266.

\section{Etymology}

The specific epithet relates to its external similarity to a tineid moth.

\section{Brusqeulia atrograpta sp. $\mathbf{n}$.}

\section{Diagnosis}

(Figs 25, 26, 51)

This new species is closely related to tineimorpha but completely different externally; in 
atrograpta the ground colour of the forewing is white and the markings black, and the aedeagus carries a ventro-terminal thorn.

\section{Description}

Wingspan $12 \mathrm{~mm}$. Head and thorax white, labial palpus 1.5, blackish to before end of median joint; collar, base of tegula and posterior part of thorax black. Forewing indistinctly expanding terminally; costa rather straight except for basal part, apex rounded, termen moderately oblique. Ground colour white. Markings black consisting of discontinuous basal and median fascia, subapical and terminal blotches. Cilia white-cream with black spots. Hindwing grey, whiter basally, mixed black on periphery; cilia grey.

Male genitalia (Figs 25, 26). Uncus broadest submedially with convex shoulders (probably formed by sclerotized socii); arm of gnathos expanding somewhat posteriorly; valva as in tineimorpha but with slenderer posterior part, sacculus with weaker posterior broadening; transtilla simple; aedeagus fairly broad, straight with well sclerotized ventral part terminating in a distinct thorn.

Female not known.

\section{Material examined}

Holotype male: "Brasil: M[inas]G[erais], Caraca 1300 m, 25 X 1994, V.O. Becker \& K.S. Sattler Col, Col. Becker 93550"; GS 349. Paratype, a male with identical label.

\section{Etymology}

The specific epithet is derived from the forewing colouration; Greek: ater - black, graptos - written, painted.

\section{Brusqeulia caracagena sp. $\mathbf{n}$.}

(Figs 39, 52)

\section{Diagnosis}

Facies most similar to atrograpta but in caracagena the terminal part of the forewing is devoid of black markings, limited proximally by elongate tornal marking; differs from Joaquima tricolora RAZOWSKI \& BECKER, 1999 from Paraná in the lack of a reddish base to the forewing.

\section{Description}

Wingspan $15 \mathrm{~mm}$. Head white, with greyer vertex; labial palpus ca 1.5 blackish medially and in basal part of terminal joint; thorax white, tegula black basally. Forewing indistinctly expanding terminad; costa almost straight; apex rounded; termen oblique, straight. Ground colour white in terminal third of wing indistinctly mixed pinkish; 
strigulation blackish. Markings consist of black marks on dark grey background; basal blotch divided into several parts; median fascia interrupted subcostally; subapical blotch connected with tornal blotch; a row of black spots along termen. Cilia greyish white. Hindwing brownish grey, cilia slightly paler.

Male not known.

Female genitalia (Fig. 39). Papilla analis fairly large; apophyses posteriores slender; apophyses anteriores reduced; eighth tergite large with spiny ventro-median edges; sterigma oval proximally, elongate posteriorly, rather weakly sclerotized medially; ductus bursae short, slender; corpus bursae large pear-shaped, without any sclerites.

Scent scales in posterior part of subgenital sternite anteriorly to sclerotized posterior edge forming at its lateral ends a differentiated patch similar to that in middle of lateral edges of sterigma.

\section{Material examined}

Holotype female: "Brasil: M[inas]G[erais], Caraca 1300 m, 7-10 V 1996, V.O. Becker Col; Col. Becker 108174"; GS 350. Paratype, similar label but the altitude $1400 \mathrm{~m}$, Serra do Cipo, 17-19 IV 1991, Col. Becker 78150.

\section{Etymology}

The name concerns the place of origin Caraca; Greek: genos - descendent.

\section{Remarks}

The paratype has a paler ground colour and forewing markings slightly different from those of the holotype.

\section{Brusqeulia baeza sp. n.}

(Figs 27, 28, 53)

\section{Diagnosis}

This species is related to monoloba as the shapes of the socii and aedeagus show, but baeza has a hooked black costal blotch, a short ventro-terminal projections to the aedeagus and sacculus.

\section{Description}

Wingspan $15 \mathrm{~mm}$. Head pale brownish grey, frons and end of labial palpus (1.5) white; thorax greyish cream, collar blackish. Forewing not really expanding terminally, costa almost straight, termen oblique. Ground colour cream with indistinct yellow-brown admixture in basal half of wing and darker, yellower strigulae in terminal area. Markings black represented by a hooked postmedian costal blotch followed by a smaller subapical 
blotch. Cilia cream. Hindwing brownish grey; cilia paler.

Male genitalia (Figs 27, 28). Uncus slender, slightly tapering terminally; socius elongate; gnathos rather short; valva broad with costa well sclerotized, curved upward; sacculus sinuate with small ventral projection; transtilla simple, broadening laterally; aedeagus fairly slender with short ventral part and long dorsal part; coecum penis large.

Female not known.

\section{Material examined}

Holotype male: "Ecuador: Napo, Baeza 2000 m, 29 XII 1992, V.O. Becker Col; Col. Becker 104236"; GS 433.

\section{Etymology}

The specific epithet is based on the name of the type locality.

\section{Brusqeulia monoloba sp. $\mathbf{n}$.}

\section{Diagnosis}

(Figs 29, 30, 54)

B. monoloba is externally similar to sebastiani but its male genitalia are close to atrograpta, differing from them chiefly in having a single ventral lobe at the end of the sacculus and a broad lobe on the dorsum of the transtilla.

\section{Description}

Wingspan $13 \mathrm{~mm}$. Head and thorax cream, labial palpus ca 1.5, browner. Forewing scarcely expanding terminally with termen moderately oblique. Ground colour yellowish cream with indistinct brownish yellow suffusion and fine brownish strigulation. Markings brown consisting of costal remnant of postbasal fascia and large subapical triangle. Cilia brownish cream with diffuse darker interruptions. Hindwing cream, brownish grey on peripheries, with indistinct, sparse strigulation subapically. Cilia paler than wing.

Male genitalia (Figs 29, 30). Uncus fairly broad; socius elongate; arm of gnathos moderately broad; valva broad basally, distinctly tapering terminally in distal third; sacculus incised postmedially with rounded ventro-posterior termination; dorsal lobe of transtilla helmet-shaped; aedeagus large, broad, with ventro-terminal projection.

Female not known.

\section{Material examined}

Holotype male: "Brasil: M[inas]G[erais], Caraca 1300 m, 25 X 1994, V.O. Becker \& K.S. Sattler Col; Col. Becker 93574"; GS 365. 

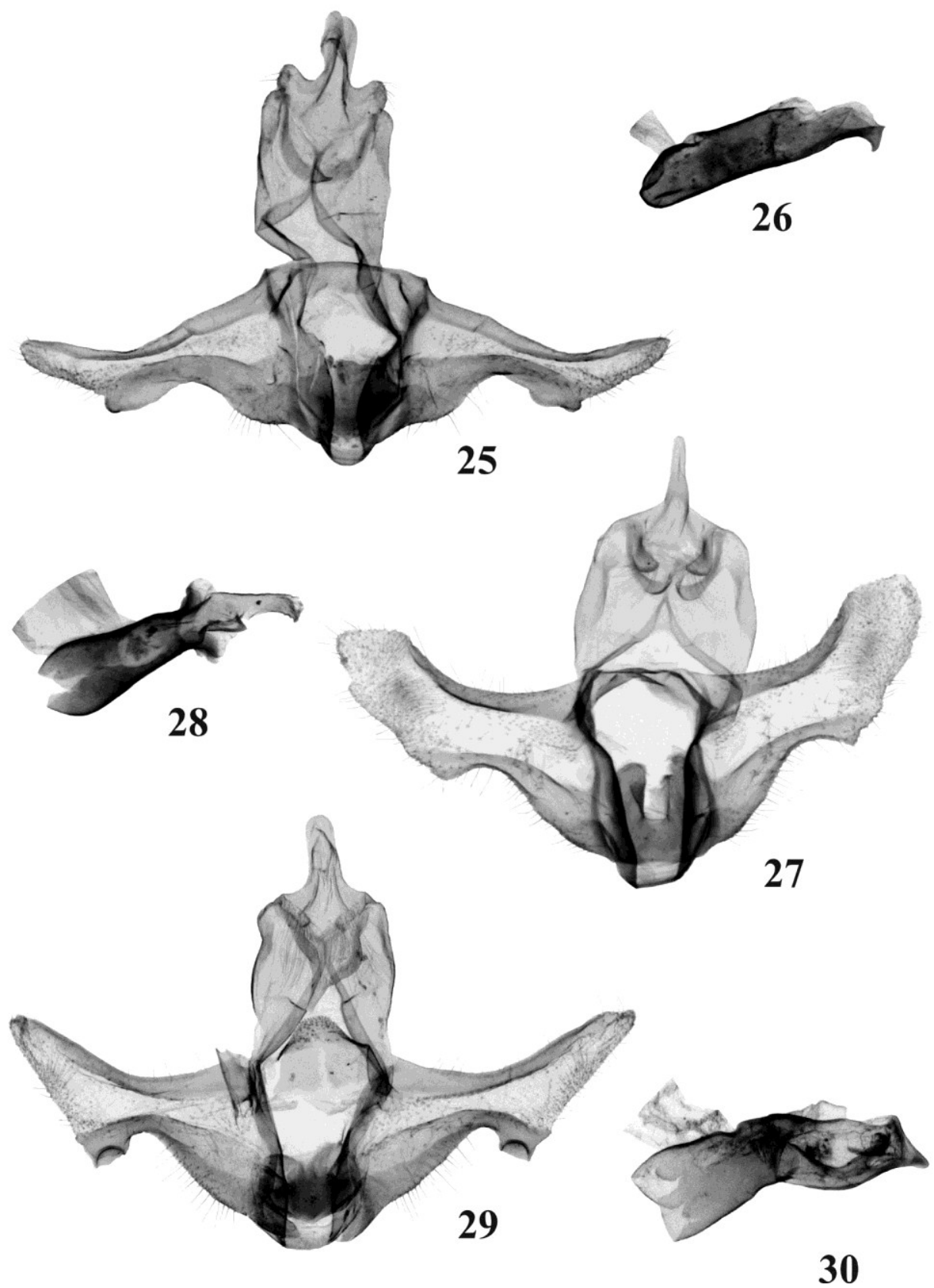

Figs 25-30. Male genitalia. 25, 26 - Brusqeulia atrograpta sp. n., holotype; 27, 28 - Brusqeulia baeza sp. n., holotype; 29, 30 - Brusqeulia monoloba sp. n., holotype. 


\section{Etymology}

The specific name refers to the termination of the sacculus; Greek: lobos - lobe, monos - singular.

\section{Brusqeulia jacupiranga sp. $\mathbf{n}$.}

(Figs 31, 32, 55)

\section{Diagnosis}

This species is related to monoloba (similar socii, sacculus and aedeagus) but jacupiranga is easily distinguished by the very long processes of the transtilla; the colouration is similar to that of tineimorpha but the latter has a very slender forewing and an oblique termen.

\section{Description}

Wingspan $12 \mathrm{~mm}$. Head and base of tegula cream brown, labial palpus ca 1.5, cream terminally; thorax grey. Forewing uniformly broad throughout; costa gradually convex, more so at base; termen short, moderately oblique, straight. Ground colour white with rather large grey suffusions and blackish marginal dots. Markings grey-black with paler places; weak pale ferruginous marks in subdorsal, subterminal and terminal parts of wing. Cilia cream ferruginous. Hindwing grey whiter basad, cilia grey.

Male genitalia (Figs 31, 32). Uncus slender, rounded apically; socius fairly long; arm of gnathos with curved terminal process; valva weakly broadening basally; sacculus sinuate postmedially with large ventro-terminal lobe; median part of transtilla with pair of very long, slender processes; aedeagus broad with short ventral termination.

Female not known.

\section{Material examined}

Holotype male: "Brasil: S[ăo]P[aulo], Jacupiranga 800 m, 8 II 1993, V.O. Becker Col; Col. Becker 87553"; GS 376.

\section{Etymology}

The specific epithet is based on the name of the type locality.

\section{Brusqeulia atrocentra sp. $\mathbf{n}$.}

\section{Diagnosis}

(Figs 33, 34, 56)

Facies distinct from all congeners; forewing with black median dot; closely related to atrograpta, but in atrocentra the sacculus has a larger subterminal lobe and the aedeagus a long termination. 


\title{
Description
}

Wingspan $13 \mathrm{~mm}$. Head cream; labial palpus ca 1.5, white posteriorly; thorax more olive brownish than head, grey proximally. Forewing not expanding terminad, costa convex basally, termen oblique, almost straight. Ground colour olive cream sprinkled brownish cream; costa delicately strigulated brownish; black dot at end of median cell. Cilia cream. Hindwing pale brownish cream, paler basally; cilia cream.

Male genitalia (Figs 33, 34). Uncus moderate, slightly tapering terminad; socii rather well sclerotized laterally, erect; gnathos arm moderate, terminal plate well developed; valva broad at base, costa concave, distal part slender; sacculus broad, deeply concave medially with subterminal lobe and slender posterior part; transtilla narrowing medially, with arched median fold; aedeagus fairly short with strong ventral process terminally; cornuti three minute spines; coecum penis broad.

Female not known.

\section{Material examined}

Holotype male: "Brasil: M[inas]G[erais], Caraca 1300 m, 25 X 1994, V.O. Becker Col; Col. Becker 93551"; GS 397.

\section{Etymology}

This name refers to the presence of the black dot at the end of the forewing median cell; Latin: ater - black, centrum - centre.

\section{Brusqeulia tripuncta RAZOWSKI \& BECKER, 2000}

(Fig. 57)

\author{
Material examined \\ One specimen from the type locality: Capitao Poco, Paraná.
}

\section{Limeulia RAZOWSKI \& BECKER, 2000}

This genus was described as monotypic. It was compared with Pinhaisania RAZOWSKI \& BECKER, 2000.

\section{Limeulia cimoliochroa sp. $\mathbf{n}$.}

(Figs 35, 36, 58)

\section{Diagnosis}

Facies as Brusqeulia uncicera and ceriphora but the forewing ground colour of this species is ferruginous cream and the sacculus is slender and strongly curved. This new 
species differs from curiosa in having a slender, smooth sacculus.

\section{Description}

Wingspan $10 \mathrm{~mm}$. Head white, labial palpus ca 2 marked grey postmedially; thorax whitish, tegula cream. Forewing as in uncicera. Ground colour pale ferruginous cream whiter in basal half of costal area; dots and markings black; costal spots accompanied by a streak in distal part of median cell; cilia concolorous with ground colour with a few black spots corresponding with terminal spots. Cilia whitish grey, transparent, grey posteriorly; cilia paler.

Male genitalia (Figs 35, 36). Uncus fairly large, expanding and rounded terminally; socius small; gnathos moderate with pointed terminal plate; valva strongly tapering terminally from beyond sacculus; sacculus broad basally, angulate before distinct ventral incision, termination slender, pointed; transtilla fairly broad laterally; aedeagus expanding terminally, convex ventro-terminally; cornuti six fine spines.

Female not known.

\section{Material examined}

Holotype male: "Brasil: M[inas]G[erais], Nova Lima 850 m, 1-3 IV 1982, V.O. Becker Col; Col. Becker 50765"; GS 358.

\section{Etymology}

The specific name refers to the colouration of the forewing ground colour; Greek: from Kimolos, the island providing clay, indirectly, clay colour; pteron - wing.

\section{Ibateguara gen. $\mathbf{n}$.}

Type-species: Ibateguara spinosissima $\mathrm{sp} . \mathrm{n}$.

\section{Diagnosis}

The new genus is closely related to Brusqeulia as far as one can judge from the facies of the type-species, and the shape of the valva and sacculus, but Ibateguara has a large, setose socius and membranously connected gnathos arms.

\section{Description}

Socius slender, ca 1.5 the diameter of the eye; forewing slender; venation as in Brusqeulia.

Male genitalia. Uncus short, well sclerotized, naked; socius broad, oval, densely clothed with strong, specialized spines; arms of gnathos connected by means of a membrane; vinculum slender; valva broad to about middle with well sclerotized costa and slender posterior third; sacculus broad to beyond middle, angulate, sinuate posteriorly, with long, sharp ventral termination; transtilla a simple band; juxta broad; aedeagus slender, simple. 

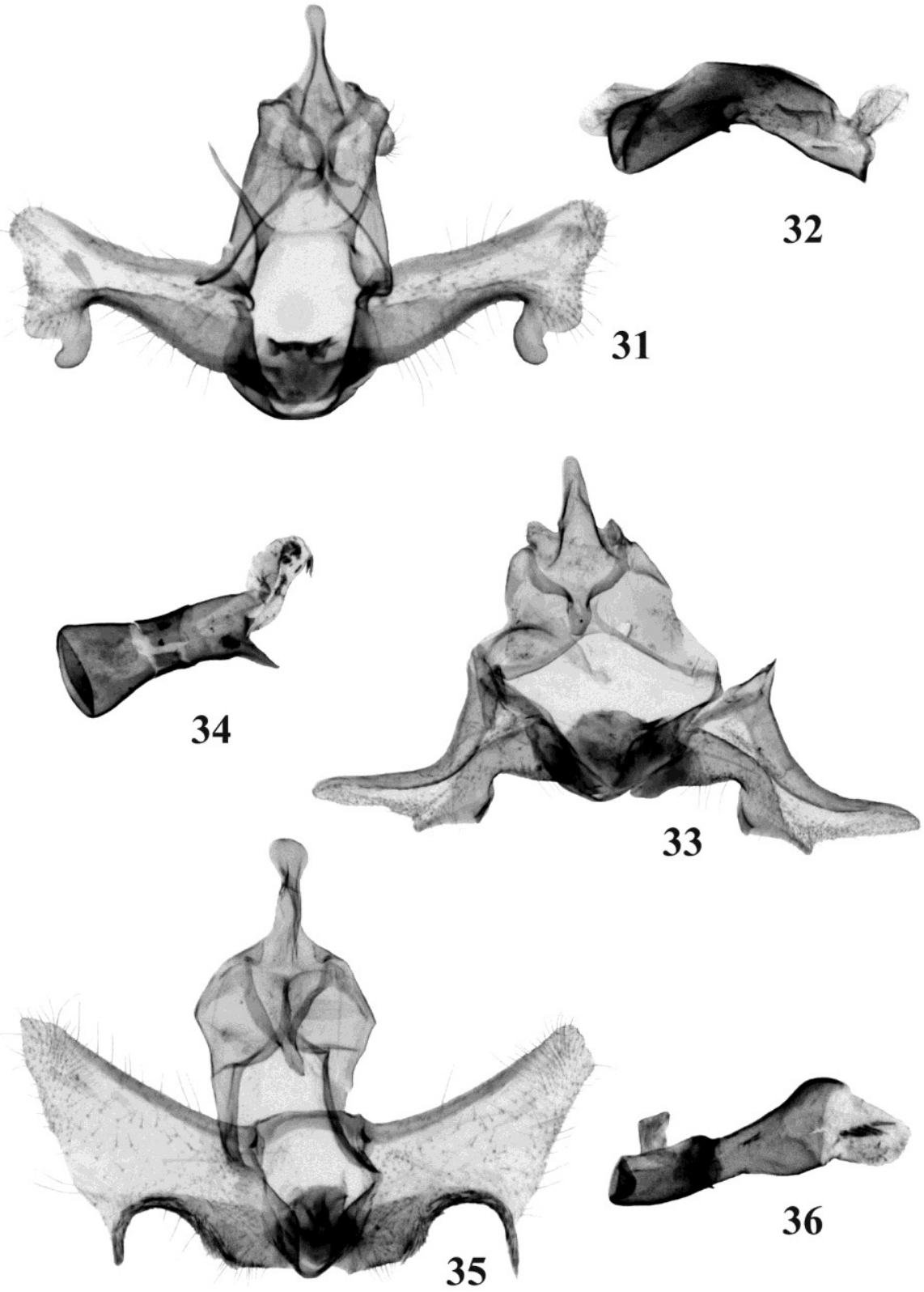

Figs 31-36. Male genitalia. 31, 32 - Brusqeulia jacupiranga sp. n., holotype; 33-34 - Brusqeulia atrocentra sp. n.; 35, 36 - Limeulia cimoliochroa sp. n., holotype. 
Female not known.

\section{Etymology}

The generic name is based on the name of the type locality of the type-species.
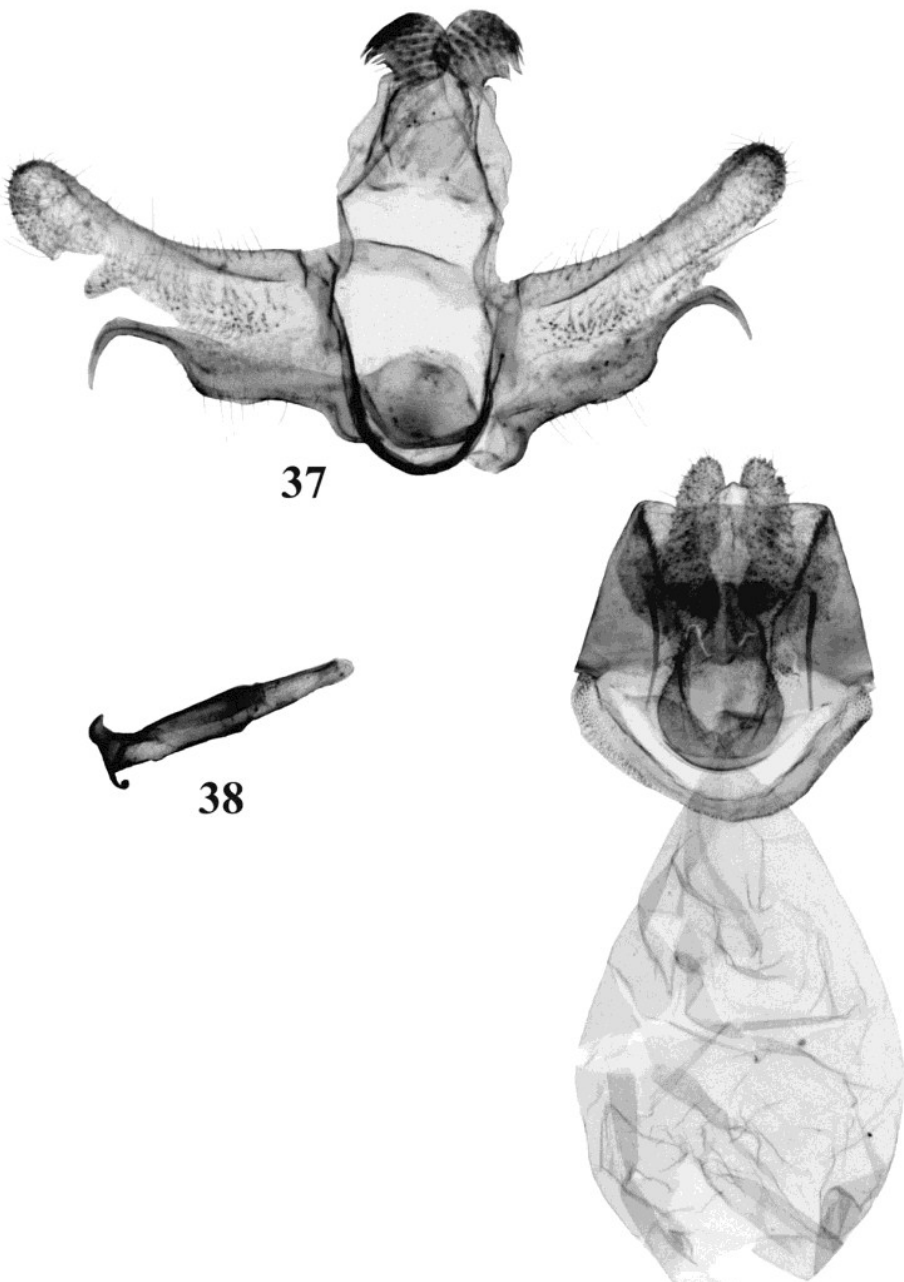

Figs 37-39. Male and female genitalia. 37, 38 - Ibateguara spinosissima sp. n., holotype; 39 Brusqeulia caracagena sp. n., holotype. 

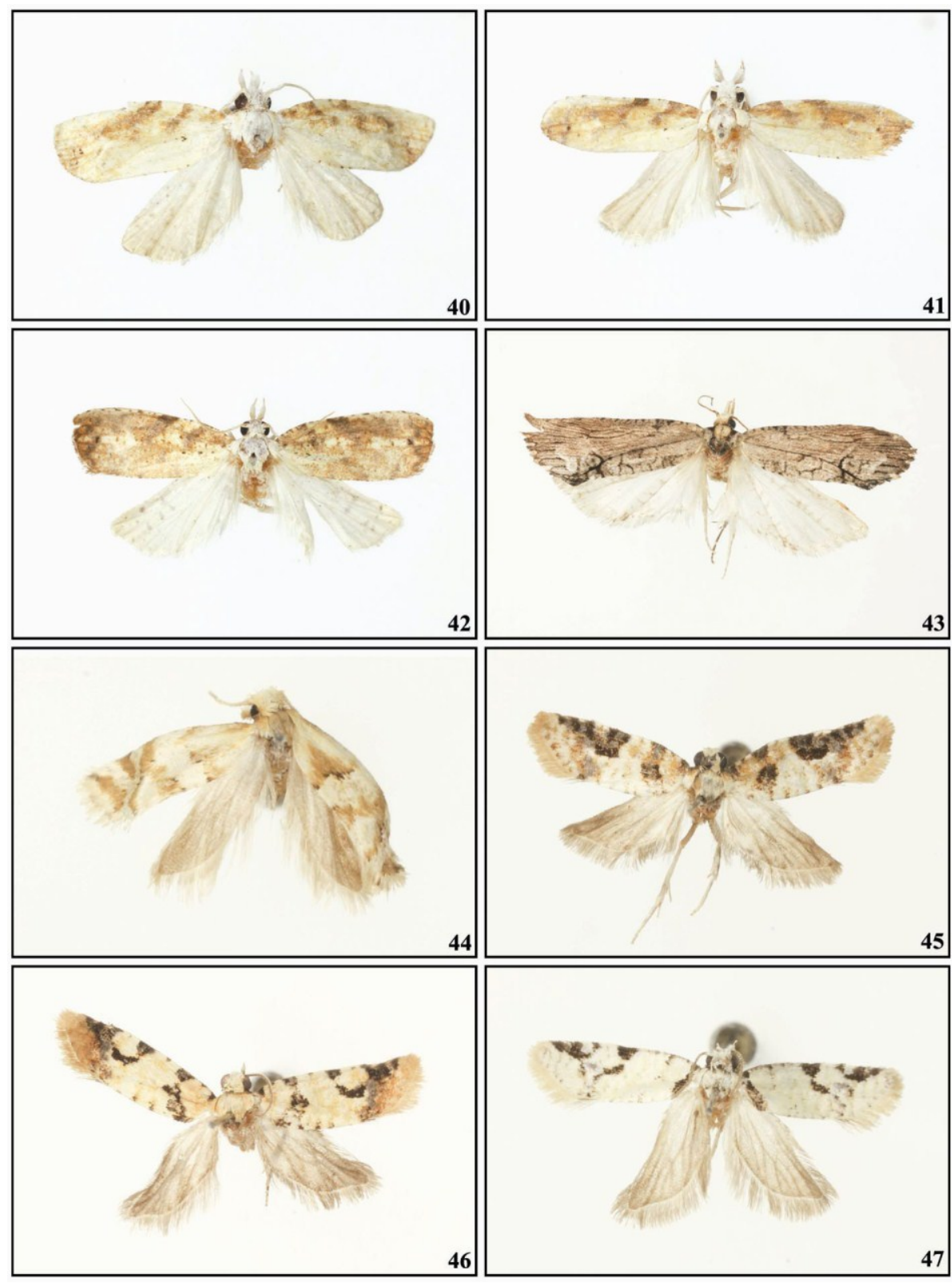

Figs 40-47. Adults. 40 - Hynhamia albicorpus sp. n., holotype; 41 - Hynhamia bahiana sp. n., holotype; 42 - Hynhamia diversa sp. n., holotype; 43 - Ayazua hyeroglyphica sp. n., holotype; 44 Ramaperta telemaca sp. n., holotype; 45 - Brusqeulia guaramiranga sp. n., holotype; 46 - Brusqeulia ceriphora sp. n., holotype; 47 - Brusqeulia uncicera sp. n., holotype. 

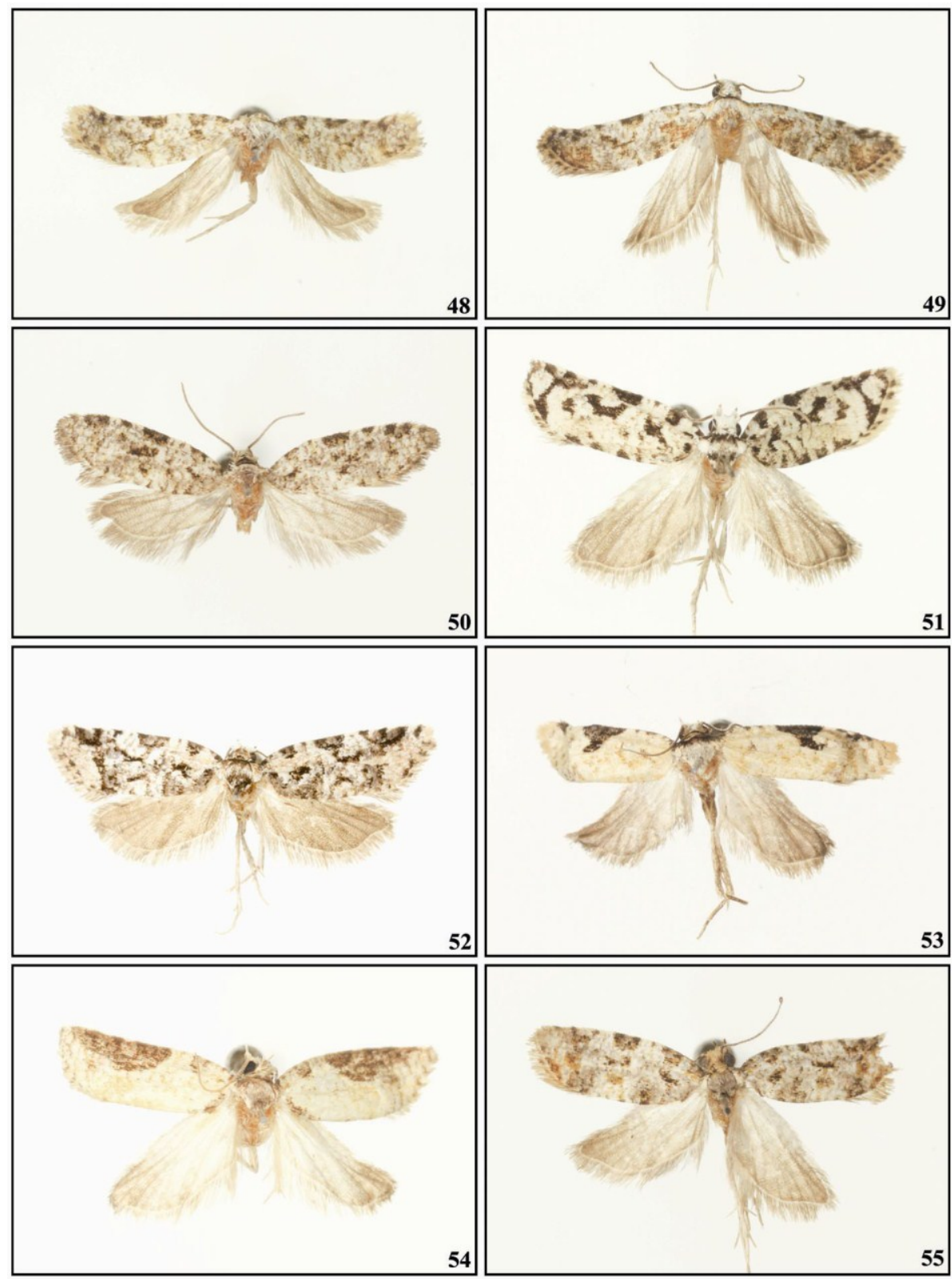

Figs 48-55. Adults. 48 - Brusqeulia costispina sp. n., holotype; 49 - Brusqeulia bonita sp. n., holotype; 50 - Brusqeulia tineimorpha sp. n., holotype; 51 - Brusqeulia atrograpta sp. n., holotype; 52 - Brusqeulia caracagena sp. n., holotype; 53 - Brusqeulia baeza sp. n., holotype; 54 - Brusqeulia monoloba sp. n., holotype; 55 - Brusqeulia jacupiranga sp. n., holotype. 


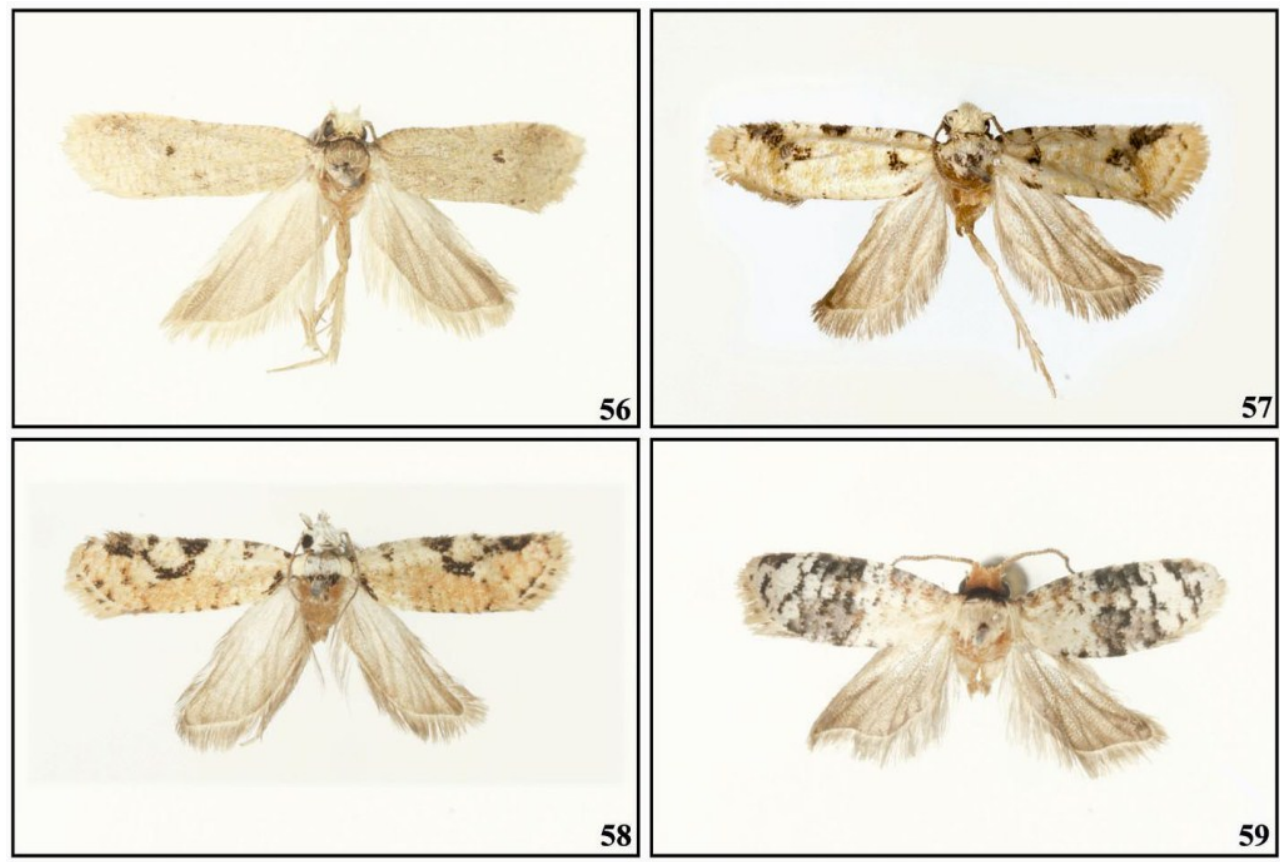

Figs 56-59. Adults. 56 - Brusqeulia atrocentra sp. n., holotype; 57 - Brusqeulia tripuncta Razowski \& Becker, 2000, Para, Brazil (Capitao Poco); 58 - Limeulia cimoliochroa sp. n., holotype; 59 Ibateguara spinosissima sp. n., holotype.

\section{Ibateguara spinosissima sp. $\mathbf{n}$.}

(Figs 37, 38, 59)

\section{Diagnosis}

This is the only species of the genus characterized above; the pattern is somewhat similar to that of B. atrograpta, and the valva resembles that of $B$. cimoliochroa.

\section{Description}

Wingspan $11 \mathrm{~mm}$. Head cream ferruginous, labial palpus darker cream terminally; thorax whitish, black-brown proximally. Forewing not expanding terminally; costa scarcely convex; termen weakly oblique, slightly sinuate. Ground colour silver white; strigulation black on both ground colour and markings; median fascia broad, subapical blotch small, both greyish. Cilia whitish tinged pale ochreous posteriorly. Hindwing grey, cilia similar.

Male genitalia (Figs 37, 38) as described for the genus. 


\section{Material examined}

Holotype male: "Brazil: Al[agoas], Ibateguara 400 m, 10-20 III 1994, V.O. Becker Col; Col. Becker 9070"; GS 261.

\section{Etymology}

The specific epithet refers to the spinulation of the socii; Latin: spinosissima - the most spined.

\section{REFERENCES}

BRown J.W. 1990. Review of Hynhamia RAzOwSKI (Lepidoptera: Tortricidae) and critique of its phylogenetic position. Entomologica Scandinavica 21: 321-328.

RAZOWSKI J. 1987. Neotropical Chlidanotini (Lepidoptera, Tortricidae). Bulletin de l'Académie Polonaise des Sciences, Série des Sciences Biologiques 35: 61-71.

RAZOWSKi J., BeCKER V.O. 1999. Descriptions of four new Neotropical Euliini genera (Lepidoptera: Tortricidae) and their species. Polskie Pismo Entomologiczne 68: 407-414.

RAzowski J., BeCKeR V.O. 2000a. Description of three North Andean genera of Euliini and their seven species (Lepidoptera: Tortricidae). SHILAP Revista de Lepidopterologia 28: 109-117.

RaZOWSKi J., BECKER V.O. 2000b. Description of six Brazilian genera of Euliini and their species (Lepidoptera: Tortricidae). SHILAP Revista de Lepidopterologia 28: 385-393.

Razowski J., Pelz V., 2007. Hynhamia Razowski, Dimorphopalpa Brown, and Ulvipinara gen. n., three euliine genera from Ecuador (Lepidoptera: Tortricidae). Polish Journal of Entomology 76: 21-40.

Razowski J., Pelz V., Wojtusiak J. 2007. Re-definition of Toreulia with description of four new species (Lepidoptera: Tortricidae). Genus 18: 107-115.

Received: December 17, 2010

Accepted: February 25, 2011 